\title{
Monialaisuus maatilan strategisena valintana
}

\author{
Margit Närvä ${ }^{l)}$, Leena Rantamäki-Lahtinen ${ }^{2)}$ ja Matti Ryhänen ${ }^{l)}$ \\ 1) Seinäjoen ammattikorkeakoulu, SeAMK Elintarvike ja maatalous, Ilmajoentie 525, 60800 Ilmajoki, etu- \\ nimi.sukunimi@seamk.fi \\ ${ }^{2)}$ MTT taloustutkimus, Latokartanonkaari 9,00790 Helsinki, leena.rantamaki-lahtinen@mtt.fi
}

\section{Tiivistelmä}

Maatalouden toimintaympäristössä tapahtuvat muutokset luovat haasteita maatilojen menestymiselle. Maatalousyrittäjien on mietittävä, missä liiketoiminnoissa ja missä laajuudessa, he aikovat olla mukana. Yhtenä vaihtoehtona on maatilan monialaistaminen eli maa- ja metsätalouden lisäksi harjoitetaan myös muuta yritystoimintaa. Tällaisten monialaisten maatilojen määrä ja suhteellinen osuus kaikista tiloista on kasvanut koko EU:n alueella. Monialaisten maatilojen strategisesta johtamisesta on olemassa vain niukalti tietoa, etenkin seuranta-aineistoja on vähän. Tämän tutkimuksen tavoitteena on tarkastella monialaisia maatiloja strategisen johtamisen näkökulmasta ja kuvailla miten suomalaiset monialaiset tilat ovat kehittyneet ajan saatossa.

Aineistona käytetään kolmea kyselytutkimusta, jotka toteutettiin vuosina 2001, 2006 ja 2012. Tässä artikkelissa analysoidaan vuonna 2001 monialaisina maatiloina toimineita yrityksiä, joista on saatavana paneeliaineistoa kaikilta kolmelta vuodelta. Lisäksi analysoidaan maatalouden ja muun yritystoiminnan kehittymistä sellaisilla monialaisilla maatiloilla, jotka vastasivat kyselyyn vuosina 2006 ja 2012. Tutkimus on luonteeltaan kuvailevaa, eikä siinä esitetä syy-seuraus suhteita. Tilastollisina analyysimenetelminä käytettiin ei-parametrista Kruskall-Wallisin testiä ja $\mathrm{X}^{2}$-testiä.

Tulosten mukaan useimmat vuonna 2001 monialaisina toimineet tilat olivat edelleen monialaisia vuonna 2012. Monialaistamisella on useimmiten tavoiteltu riskien vähentämistä, lisätuloja ja tasaisempaa tulovirtaa. Maatilan monialaistamispäätöksen taustalla on usein ollut yritys sopeutua muuttuneeseen toimintaympäristöön. Osalla tiloista monialaistaminen on huolella valittu pitkän tähtäimen strategia, jossa lähtökohtana on ollut havaittu mahdollisuus. Monialaistamisstrategian valintaan vaikuttavat myös muut kuin taloudelliset syyt. Tulosten mukaan monialaiset tilat suunnittelevat voimavarojen käyttöä keskipitkällä ajanjaksolla.

Monialaisten tilojen maataloudessa on vuosien mittaan tapahtunut muutoksia. Noin $42 \%$ vastanneista on vaihtanut maatalouden tuotantosuuntaa. Kolmannes vastanneista on luopunut kotieläintuotannosta, kun taas noin joka yhdeksäs on laajentanut kotieläintuotantoa. Kolmannes vastanneista on hankkinut lisäpeltoa, kun taas joka viides on antanut osan pelloista vuokralle. Vastanneiden monialaisten maatilojen yhteenlaskettu liikevaihto on kasvanut noin $15 \%$ aikavälillä 2006-2011. Kun huomioidaan kyseisen aikavälin inflaatio, on yhteenlaskettu liikevaihto pysynyt lähes muuttumattomana. Monialaisten tilojen harjoittama maatalous ja muu yritystoiminta ovat vastaajien yhteenlasketulla liikevaihdolla mitattuna olleet suunnilleen samansuuruiset ja liikevaihto on kehittynyt maataloudessa ja muussa yritystoiminnassa samansuuntaisesti.

Asiasanat: monialainen tila, johtaminen, paneeliaineisto, strategia 


\section{Johdanto}

Meneillään olevassa rakennemuutoksessa maatilojen koko kasvaa ja määrä vähenee. Uusi tuotantoteknologia muuttaa toimintaympäristöä, tuotantoprosessit ja markkinat muuttuvat, mikä tuo kehittämishaasteen. McElwee (2006, 187-188) esittää maatalousyrittäjille sopiviksi kehittämisstrategioiksi: toiminnan laajentaminen peltoa lisäämällä, kotieläintuotannon laajentaminen, lisäarvon tuottaminen vertikaalisella integraatiolla, maatalouden ulkopuolinen liiketoiminta, yhteistyö muiden maatalousyrityksien kanssa, monialaistaminen, maatalouden lopettaminen, työssäkäynti tilan ulkopuolella, kapasiteetin erilainen hyödyntäminen erikoistumalla, ja olla tekemättä mitään.

Monet suomalaiset maatalousyrittäjät ovat valinneet monialaistamisstrategian. Tällä tarkoitetaan, että he harjoittavat myös jotain muuta yritystoimintaa perinteisen maa- ja metsätalouden lisäksi. Tällaisia monialaisia maatiloja on noin joka kolmas suomalainen maatila. Maatilojen monialaisuuden rooli osana maatilataloutta ja maaseudun yrittäjyyttä on kasvanut. Vuosina 2000-2007 monialaisten maatilojen määrä kasvoi, vaikka samaan aikaan maatilojen kokonaismäärä väheni. Vuonna 2010 monialaisten maatilojen määä tasaantui vajaaseen 20 000. (Rantamäki-Lahtinen 2002, 2004; MMMtike 2011.) Monialaisuus vaihtelee myös tilajoukon sisällä. Monialaisuus on yleistä isoilla kasvinviljelytiloilla ja erikoiskasvintuotantoa harjoittavilla tiloilla (MMMtike 2011; European Commission 2008).

Monialaisten maatilojen määrä ja osuus on kasvanut Euroopan unionin alueella (European Commission 2008). Perinteistä maataloutta harjoittavien maatilojen osuus maaseudun yritysjoukosta vähenee, kun taas ilman maatilataustaa toimivien yritysten osuus kasvaa (Rantamäki-Lahtinen ym. 2007). Siten monialaiset maatilat ovat tärkeä osa suomalaista maaseutua. Maatilan monialaistamisen taustalla on usein lisätulojen tarve, vähentyneet tulot muista lähteistä sekä kausittaisten vaihtelujen tasaaminen niin tulojen kuin työkuormituksen osalta (Rantamäki-Lahtinen 2004). Montanalaisilla maatilamatkailuyrittäjillä taloudelliset tekijät, kuten maatalouden tulojen vaihtelujen tasaaminen, verokannustimet ja markkinoiden kysyntä olivat tärkeitä tekijöitä (Nickerson ym. 2001). Norjassa maatilojen monialaistamisen motiivina muut syyt kuin lisätulojen tarve olivat olennaisimpia (Vik ja McElwee 2011).

Yritystoimintaa on suunniteltava strategisesti (Ansoff 1987; Kay ym. 2008). Strategian suunnittelu jakautuu kolmelle tasolle: yritystason strategia, liiketoimintatason strategia ja toimintotason strategia $(\mathrm{mm}$. Hofer ja Schendel 1978; Bamberger ja Bonacker 1994). Yrityksen tasolla strateginen suunnittelu koskee koko yritystä, ja siinä määritellään toiminnan laajuus, missä liiketoiminnoissa ollaan mukana ja miten resurssit jaetaan eri liiketoiminnoille. Liiketoimintatasolla laaditaan kilpailustrategiat, joilla haetaan kilpailuetua suhteessa kilpailijoihin. Tällöin päätetään $\mathrm{mm}$. siitä, pyrkiikö yritys erilaistamaan tuotteita ja hakemaan kilpailuetua sitä kautta, vai tavoitteleeko se kustannusjohtajuutta. Toimintatason strategisessa suunnittelussa keskitytään tiettyyn rajattuun osa-alueeseen. Maatilan monialaisuus on yritystason strateginen päätös. Yrittäjän on mietittävä maatalouden ja muun yritystoiminnan osalta, missä liiketoiminta-alueissa on mukana ja mistä liiketoiminta-alueesta mahdollisesti luopuu. Monialaisten maatilojen yrittäjät päivittävät strategiaansa tarvittaessa ja tekevät erilaisia valintoja; osa jatkaa monialaisena, osa luopuu maataloudesta ja osa muusta yritystoiminnasta.

Tämän tutkimuksen tavoitteena on tarkastella monialaisia maatiloja strategisen johtamisen näkökulmasta ja kuvailla, miten suomalaisia monialaisia maatiloja on kehitetty ajan saatossa. Tutkimuksessa vastataan seuraaviin kysymyksiin:

- Mitkä tekijät ovat vaikuttaneet siihen, että monialaisten maatilojen yrittäjät ovat valinnet monialaistamisstrategian ja jatkaneet sitä?

- Miten muu yritystoiminta ja maatalous ovat kehittyneet monialaisilla maatiloilla?

\section{Aineisto ja menetelmät}

Aineisto on osa laajaa kyselyaineistoa (Rantamäki-Lahtinen 2013). Aineisto koostuu kolmesta pääryhmästä: 1) ilman maatilakytkentää toimivat maaseutuyritykset, 2) monialaiset maatilat ja 3) perustuotantotilat. Aineisto hankittiin vuosina 2001, 2006 ja 2012. Artikkelin aineisto koostuu 173 tilan paneeliaineistosta. Vuonna 2001 aineiston tilat olivat monialaisia ja ne osallistuivat kyselyyn kaikkina kyselyvuosina.

Lisäksi tarkastellaan maatalouden ja muun yritystoiminnan kehittämistä maatiloilla, jotka vastasivat kyselyyn vuosina 2006 ja 2012 ja olivat vuonna 2006 monialaisia. Aineistoksi tuli 223 tilaa. Aineistosta poistettiin tilat, joilta puuttui havaintoja työnkäytöstä ja liikevaihdosta. Poiston jälkeen aineiston koko oli 152 tilaa. Aineistosta jouduttiin poistamaan myös tilat, joilta puuttui havaintoja investoinneista ja nettotuloksen osuuksista. Aineistoon jäi 103 tilaa. 
Tilastollisina analyysimenetelminä käytettiin ei-parametrista Kruskall-Wallisin testiä ja $\mathrm{X}^{2}$-testiä. Tutkimus on luonteeltaan kuvailevaa, eikä siinä esitetä syy-seuraus suhteita. Aineisto on vastauskadon takia valikoitunutta, joten tuloksia ei voida yleistää kaikkiin suomalaisiin monialaisiin tiloihin.

\section{Tulokset}

Mitkä tekijät ovat vaikuttaneet siihen, että monialaisten maatilojen yrittäjät ovat valinnet monialaistamisstrategian ja jatkaneet sitä?

Tutkimuksessa mukana olevasta 173:sta vuoden 2001 monialaisesta maatilasta vuonna 2012 monialaistamisstrategiaa jatkoi 102 tilaa, 21 tilaa oli lopettanut maatalouden harjoittamisen ja harjoitti muuta yritystoimintaa, 20 tilaa oli lopettanut muun yritystoiminnan harjoittamisen ja harjoitti maataloutta ja 30 tilaa oli lopettanut sekä maatalouden että muun yritystoiminnan (kuvio 1). Lopettamisen syynä oli usein yrittäjän korkea ikä. Myöhemmin näistä eri strategiavalinnan tehneistä ryhmistä käytetään nimitystä strategiaryhmät.

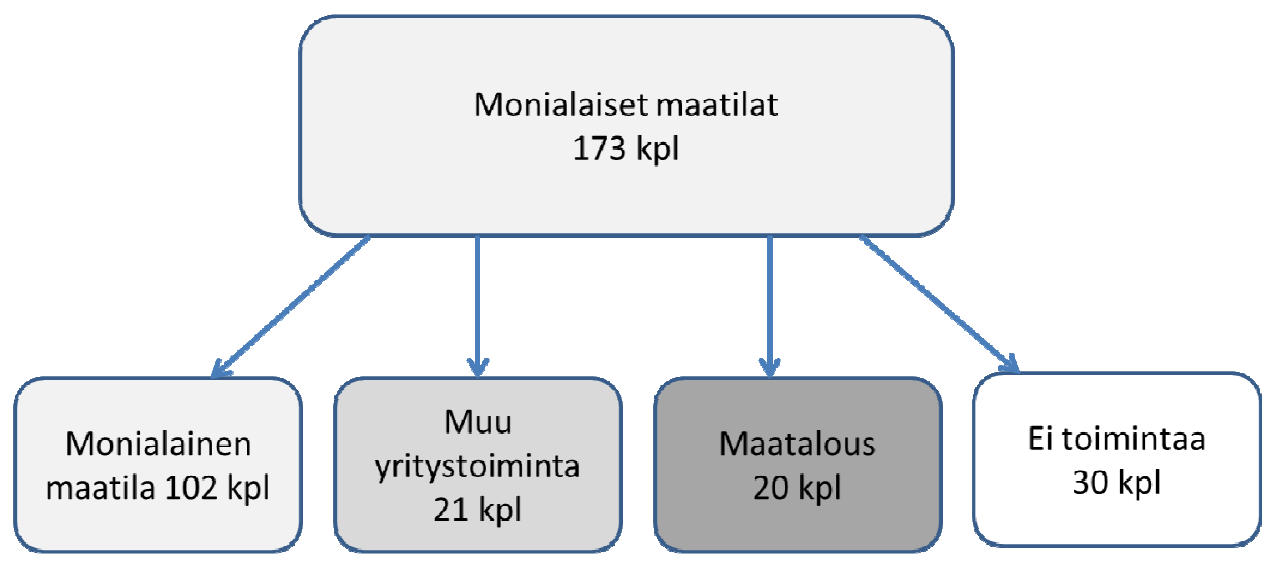

Kuvio 1. Tutkitut strategiaryhmät.

Vuonna 2001 vastaajilta kysyttiin, millaisia odotuksia heillä oli aloittaessaan muun yritystoiminnan harjoittamisen. He arvioivat odotuksia asteikolla $0-2$, jossa $0=$ ei odotuksia, $1=$ ensisijainen odotus ja $2=$ toissijainen odotus. Vaihtoehtoina olivat: jatkojalostamalla tuotteille saisi paremman hinnan, monialaisuus tasaisi tulojen kausiluonteisuutta, monialaisuus takaisi korkeamman toimeentulon, yrityksen laajentaminen onnistuisi helpommin maatalouden ulkopuolelle, saisimme olemassa olevat koneet tehokkaampaan käyttöön, saisimme olemassa olevat rakennukset tehokkaampaan käyttöön, monialaisuus tasaisi maatalouden riskejä. Yleisimmin odotukset liittyivät maatalouden riskien tasaamiseen, korkeamman toimeentulon saavuttamiseen sekä maatalouden tulojen kausiluonteisuuden tasaamiseen. Eri strategiaryhmien välillä odotuksissa oli eroja ainoastaan riskien hallinnassa. Odotus riskien vähentämisestä oli tärkeintä niille monialaisille maatiloille, jotka olivat monialaisia vielä vuonna 2012 ja vähiten tärkeä niille, jotka myöhemmin keskittyivät maatalouteen (taulukko 1).

Taulukko 1. Taustatietoja eri strategiaryhmistä.

\begin{tabular}{|l|c|c|c|c|c|}
\hline & $\begin{array}{c}\text { Monialainen } \\
2012\end{array}$ & $\begin{array}{c}\text { Muu yritystoi- } \\
\text { minta 2012 }\end{array}$ & $\begin{array}{c}\text { Maatalous } \\
2012\end{array}$ & $\begin{array}{c}\text { Ei toimintaa } \\
2012\end{array}$ & $\mathrm{p}$ \\
\hline $\begin{array}{l}\text { \% maatiloista oli riskien vähentämi- } \\
\text { seen liittyviä odotuksia }\end{array}$ & $77 \%$ & $62 \%$ & $45 \%$ & $64 \%$ & $* \mathrm{c}$ \\
\hline Peltoala, ha 2001 (keskiarvo & 40,5 & 43,1 & 24 & 34,4 & $*$ \\
\hline Kotieläintiloja (\%) 2001 & $36 \%$ & $25 \%$ & $47 \%$ & $45 \%$ & - \\
\hline Kotieläintiloja (\%) 2012 & $24 \%$ & - & $53 \%$ & $1988-1994$ & \\
\hline $\begin{array}{l}\text { Muu yritystoiminta aloitettu } \\
(95 \% \text { luottamusväli) }\end{array}$ & $1983-1989$ & $1981-1997$ & $1988-1993$ & $1989-1986$ & $* *$ \\
\hline $\begin{array}{l}\text { Maatalous aloitettu (95\% } \\
\text { luottamusväli) }\end{array}$ & $1984-1989$ & $1973-1981$ & $1985-1993$ & $1978-19$ \\
\hline
\end{tabular}

$*=\mathrm{p}<0,05 ; * *=\mathrm{p}<0,01 ; \mathrm{c}=$ chi-square test, muuten testaamiseen käytetty Kruskall-Wallisin ei parametrista testiä. 
Maatilan ominaisuudet ja maataloudessa tapahtuva rakennemuutos voivat motivoida maatiloja monialaistamaan toimintaansa. Maatilat, jotka ovat jatkaneet monialaisina tai keskittyneet muuhun yritystoimintaan olivat useimmiten kasvintuotantotiloja ja niillä oli muita ryhmiä suurempi peltopinta-ala. Nämä ryhmät olivat myös aloittaneet muun yritystoiminnan harjoittamisen aikaisemmin kuin muun yritystoiminnan lopettaneet tai koko toiminnan lopettaneet. Monialaiset maatilat, jotka olivat lopettaneet toiminnan kokonaan vuoteen 2012 mennessä, olivat aloittaneet maatalouden harjoittamisen muita ryhmiä aikaisemmin ja toisaalta muun yritystoiminnan harjoittamisen myöhemmin kuin toiset.

\section{Miten muи yritystoiminta ja maatalous ovat kehittyneet monialaisilla maatiloilla?}

Yrittäjiltä kysyttiin vuosina 2001 ja 2006 monialaisen maatilana jatkamiseen liittyviä aikomuksia. Yrittäjiä pyydettiin arvioimaan väittämää 'Tulevaisuudessa harjoitamme sekä maataloutta että yritystoimintaa", Likertin-asteikolla 1-5 (1 = täysin eri mieltä, 5 = täysin samaa mieltä). Tulosten mukaan vain harva monialainen maatila aikoi vuonna 2001 muuttaa strategiaansa. Valta-osa aikoi pysyä monialaisena myös tulevaisuudessa. Vuonna 2006 usea epäili monialaisena jatkamista. Taulukosta 2 huomataan, että useassa tapauksessa strategian uudelleen arviointi tai yritystoiminnan kokonaan lopettaminen oli tiedossa useita vuosia ennen toteutusta. Toisaalta pitkän tähtäimen suunnitelmat eivät toteutuneet monessa tapauksessa, esimerkiksi muusta yritystoiminnasta vuoteen 2012 mennessä luopuneista $88 \%$ aikoi vuonna 2001 pysyä monialaisena myös tulevaisuudessa.

Taulukko 2. Suunnitelmat monialaisena pysymisestä eri strategiaryhmissä 2001 ja 2006.

\begin{tabular}{|l|c|c|c|c|}
\hline & $\begin{array}{c}\text { Monialainen } \\
2012\end{array}$ & $\begin{array}{c}\text { Muu yritystoi- } \\
\text { minta 2012 }\end{array}$ & $\begin{array}{c}\text { Maatalous } \\
2012\end{array}$ & $\begin{array}{c}\text { Ei toimintaa } \\
2012\end{array}$ \\
\hline $\begin{array}{l}\text { Aikoo olla monialainen maatila myös } \\
\text { tulevaisuudessa 2001 (arvot 4 and 5), } \%\end{array}$ & $91 \%$ & $79 \%$ & $88 \%$ & $70 \%$ \\
\hline $\begin{array}{l}\text { Aikoo olla monialainen maatila myös } \\
\text { tulevaisuudessa 2006 (arvot 4 and 5), } \%\end{array}$ & $59 \%$ & $60 \%$ & $50 \%$ & $42 \%$ \\
\hline
\end{tabular}

Tulokset osoittavat, että monialaisilla maatiloilla oli hieman pienempi liikevaihto niin maataloudessa kuin muussa yritystoiminnassa, kun verrattaan niihin ryhmiin, jotka ovat keskittyneet joko maatalouteen tai muuhun yritystoimintaan (taulukko 3). Yhteenlaskettu liikevaihto oli kuitenkin monialaisilla tiloilla isompi kuin muilla ryhmillä.

Taulukko 3. Eri strategiaryhmien liikevaihto 2006 ja 2011.

\begin{tabular}{|l|c|c|c|c|c|}
\hline Liikevaihto, 1000 $€$ & $\begin{array}{c}\text { Monialainen } \\
2012\end{array}$ & $\begin{array}{c}\text { Muu yritystoiminta } \\
2012\end{array}$ & $\begin{array}{c}\text { Maatalous } \\
2012\end{array}$ & $\begin{array}{c}\text { Ei toimintaa } \\
2012\end{array}$ & $\mathrm{p}$ \\
\hline Maatalous 2006 & 66,41 & 128,6 & 48,8 & 33,5 & \\
\hline Maatalous 2011 & 79,7 & 7,8 & 93,2 & 0 & $* *$ \\
\hline Muu yritystoiminta 2006 & 120,5 & 139,7 & 77,1 & 54,2 & $*$ \\
\hline Muu yritystoiminta 2011 & 117,9 & 142,4 & 0 & 0 & $* *$ \\
\hline
\end{tabular}

$*=\mathrm{p}<0,05 ; * *=\mathrm{p}<0,01 ;$ Kruskall-Wallis ei-parametrinen testi.

Taloudellista menestymistä arvioitiin vuosina 2006 ja 2012 subjektiivisilla mittareilla. Vastaajilta kysyttiin, miten hyvin he ovat yritystoiminnassa onnistuneet voiton maksimoinnissa, paremman elintason ansaitsemisessa itselle ja perheelle sekä toiminnan taloudellisessa kannattavuudessa. Onnistumista arvioitiin asteikolla 1-5 ( 1 = ei lainkaan, 5 = erittäin hyvin). Erot eri strategiaryhmien välillä eivät ole tilastollisesti merkitseviä (Kruskall-Wallis), mutta melkein jokaisessa väittämässä muuhun yritystoimintaan keskittyneet arvioivat onnistuneensa parhaiten (taulukko 4). 
Taulukko 4. Vastaajien mielipide onnistumisestaan yritystoiminnassa.

\begin{tabular}{|l|c|c|c|c|}
\hline & $\begin{array}{c}\text { Monialainen } \\
2012\end{array}$ & $\begin{array}{c}\text { Muu } \\
\text { yritystoiminta } \\
2012\end{array}$ & $\begin{array}{c}\text { Maatalous } \\
2012\end{array}$ & $\begin{array}{c}\text { Ei toimintaa } \\
2012\end{array}$ \\
\hline Voiton maksimointi 2006 (keskiarvo) & 2,7 & 2,9 & 2,9 & 2,9 \\
\hline Voiton maksimointi 2012 (keskiarvo) & 2,8 & 3,1 & 2,8 & - \\
\hline $\begin{array}{l}\text { Paremman elintason ansaitseminen itselle ja } \\
\text { perheelle 2006 (keskiarvo) }\end{array}$ & 3,4 & 3,5 & 3,6 & 3,4 \\
\hline $\begin{array}{l}\text { Paremman elintason ansaitseminen itselle ja } \\
\text { perheelle 2012 (keskiarvo) }\end{array}$ & 3,5 & 3,7 & 3,5 & - \\
\hline $\begin{array}{l}\text { Toiminnan taloudellinen kannattavuus 2006 } \\
\text { (keskiarvo) }\end{array}$ & 3,4 & 3,7 & 3,6 & 3,4 \\
\hline $\begin{array}{l}\text { Toiminnan taloudellinen kannattavuus 2012 } \\
\text { (keskiarvo) }\end{array}$ & 3,5 & 3,9 & 3,5 & - \\
\hline
\end{tabular}

Taulukon 5 tulokset perustuvat aineistoon, jossa mukana on 103 monialaista maatilaa, jotka vastasivat kyselyyn vuosina 2006 ja 2012. Nämä tilat luokiteltiin vuoden 2012 maatalouden päätuotantosuunnan mukaan kolmeen luokkaan. Ensimmäisen ryhmän muodostivat kasvinviljelytilat, jossa tyypillisesti päätuotantosuunnaksi oli mainittu viljanviljely. Toisen luokan muodostivat kotieläintilat, joissa päätuotantosuuntana oli maidontuotanto, naudanlihantuotanto tai sikatalous. Kolmannen ryhmän muodosti erikoiskasvintuotanto (esimerkiksi marjanviljely, perunantuotanto) tai erikoiskotieläintuotanto (lammastalous). Vastaajilta kysyttiin, miten maatalous on kehittynyt muun yritystoiminnan rinnalla. Vastaajat saivat valita kaikki sopivat vaihtoehdot (taulukko 5). Tässä ei kysytty tietyn aikavälin muutosta, vaan muutosta yleensä.

Taulukko 5. Maatalouden päätuotantosuunta vuonna 2012 sekä maataloustuotannossa tapahtunut muutos muun yritystoiminnan rinnalla.

\begin{tabular}{|l|c|c|c|c|c|c|c|c|}
\hline \multicolumn{2}{|l|}{$\begin{array}{l}\text { Maatalouden päätuotanto- } \\
\text { suunta } 2012\end{array}$} & $\begin{array}{c}\text { Luopunut } \\
\text { kotieläin- } \\
\text { tuotan- } \\
\text { nosta }\end{array}$ & $\begin{array}{c}\text { Laajenta- } \\
\text { nut ko- } \\
\text { tieläintuo- } \\
\text { tantoa }\end{array}$ & $\begin{array}{c}\text { Osa pel- } \\
\text { loista } \\
\text { annettu } \\
\text { vuokralle }\end{array}$ & $\begin{array}{c}\text { Hankittu } \\
\text { lisäpeltoa }\end{array}$ & $\begin{array}{c}\text { Mata- } \\
\text { louden } \\
\text { töitä ul- } \\
\text { koistettu }\end{array}$ & $\begin{array}{c}\text { Vaihtanut } \\
\text { tuo- } \\
\text { tanto- } \\
\text { suuntaa }\end{array}$ & $\begin{array}{c}\text { Ei } \\
\text { muutoksia } \\
\text { nykytilan- } \\
\text { teeseen }\end{array}$ \\
\hline $\begin{array}{l}\text { Kasvituotanto } \\
\text { (n=51) }\end{array}$ & $50 \%$ & $37 \%$ & $8 \%$ & $24 \%$ & $41 \%$ & $4 \%$ & $41 \%$ & $10 \%$ \\
\hline $\begin{array}{l}\text { Kotieläintuotanto } \\
(\mathrm{n}=22)\end{array}$ & $21 \%$ & $23 \%$ & $5 \%$ & $36 \%$ & $14 \%$ & $27 \%$ & $59 \%$ & $9 \%$ \\
\hline $\begin{array}{l}\text { Erikoistuotanto } \\
\text { (n=18) }\end{array}$ & $17 \%$ & $39 \%$ & $11 \%$ & $0 \%$ & $33 \%$ & $0 \%$ & $28 \%$ & $11 \%$ \\
\hline $\begin{array}{l}\text { Ei tiedossa } \\
\text { (n=12) }\end{array}$ & $12 \%$ & $25 \%$ & $33 \%$ & $8 \%$ & $33 \%$ & $0 \%$ & $33 \%$ & $8 \%$ \\
\hline $\begin{array}{l}\text { Yhteensä vas- } \\
\text { tanneista (n=103) }\end{array}$ & $100 \%$ & $33 \%$ & $11 \%$ & $20 \%$ & $33 \%$ & $8 \%$ & $42 \%$ & $10 \%$ \\
\hline
\end{tabular}

Maatalouden harjoittamisessa on tapahtunut muutoksia. Noin $42 \%$ on vaihtanut maatalouden tuotantosuuntaa. Kotieläintuotannosta on luopunut joka kolmas, kun taas joka yhdeksäs on laajentanut kotieläintuotantoa. Lisäpeltoa on hankkinut joka kolmas, kun taas joka viides on antanut osan pelloistaan vuokralle. Päätuotantosuuntanaan kasvintuotantoa harjoittavista tiloista vajaa $40 \%$ on luopunut kotieläintuotannosta, kun taas vajaa $10 \%$ on laajentanut kotieläintuotantoa. Suurempi osa päätuotantosuuntanaan kasvintuotantoa harjoittavista tiloista on hankkinut lisää peltoa kuin antanut osan pelloista vuokralle. Noin $40 \%$ vuonna 2012 päätuotantosuuntanaan kasvintuotantoa harjoittavista tiloista on vaihtanut tuotantosuuntaa. Päätuotantosuuntanaan kotieläintuotantoa harjoittavista tiloista $23 \%$ ilmoittaa luopuneensa kotieläintuotannosta. Tämä tarkoittanee, että on luovuttu jostain kotieläintuotannon osasta, koska tiloilla on edelleen päätuotantosuuntana kotieläintuotanto. Kotieläintiloilla on annettu useammin peltoa vuokralle kuin hankittu lisäpeltoa, mikä on yllättävä havainto. Taustalla lienee aikomus luopua kotieläintuotannosta. Erikoistuotantoa harjoittavilla tiloilla on monesti luovuttu kotieläintuotannosta ja keskitytty erikoiskasvintuotantoon. 
Yritysten yhteenlaskettu liikevaihto kasvoi vuodesta 2006 vuoteen 2011 noin $15 \%$. Mikäli huomioidaan kyseisen aikavälin inflaatio, liikevaihto on pysynyt lähes muuttumattomana. Vastaajat arvioivat myös maatalouden liikevaihdon vuosina 2006 ja 2011. Maatalouden ja muun yritystoiminnan liikevaihdon kehittyminen on ollut lähes saman suhteista ja ne ovat liikevaihdolla mitattuna olleet suunnilleen samansuuruiset (taulukko 6). Myös maatalouteen ja muuhun yritystoimintaan oli investoitu suunnilleen yhtä paljon.

Taulukko 6. Maatalouden ja muun yritystoiminnan liikevaihdon kehitys ( $n=95)$.

\begin{tabular}{|l|c|c|}
\hline & Maatalous, $€$ & Muu yritystoiminta, $€$ \\
\hline Vuonna 2006 & 7653000 & 8544000 \\
\hline Vuonna 2011 & 9129000 & 9989000 \\
\hline Muutos & 1476000 & 1445000 \\
\hline Muutos, \% & $19 \%$ & $17 \%$ \\
\hline
\end{tabular}

Vastaajilta kysyttiin vuosien 2006 ja 2011 osalta, kuinka suuri osuus perheen nettotuloista muodostuu yritystoiminnasta, ulkopuolisesta työssäkäynnistä ja muista tuloista (esimerkiksi eläke, pääomatulot). Taulukon 7 mukaan noin joka toisella vastaajalla yritystoiminnan osuus nettotuloista oli pienentynyt. Tämä selittynee osittain vastaajien korkeahkolla iällä.

Taulukko 7. Perheen nettotulojen muodostumisen kehitys vuosina 2006 - $2011(n=103)$.

\begin{tabular}{|l|c|c|c|}
\hline & Sama & Kasvanut & Pienentynyt \\
\hline Yritystoiminta & $19 \%$ & $31 \%$ & $50 \%$ \\
\hline Palkkatyö & $45 \%$ & $31 \%$ & $24 \%$ \\
\hline Muu & $42 \%$ & $33 \%$ & $25 \%$ \\
\hline
\end{tabular}

\section{Johtopäätökset}

Artikkelissa selvitettiin monialaisten maatilojen yritystason strategioita. Tutkimusaineiston vuoden 2001 monialaisista tiloista valtaosa jatkoi monialaisina vuonna 2012. Maatilojen muun yritystoiminnan aloittamisen motiivit vaihtelevat strategiaryhmittäin. Maatalousyrittäjien odotukset muuta yritystoimintaa aloitettaessa liittyivät useimmiten riskien vähentämiseen, tulojen lisäämiseen ja tulojen vaihteluiden tasaamiseen. Euroopan unioniin liittyminen ja sen mukanaan tuomat haasteet pakottivat maatalousyrittäjiä arvioimaan, missä liikatoiminnoissa he ovat mukana. Osa on yrittänyt reagoida muutoksiin monialaistamalla, mutta on arvioinut strategiansa uudelleen ja keskittynyt joko maatalouteen tai muuhun yritystoimintaan. Osalle monialaistaminen on ollut strateginen päätös. Usea monialaisena toimintaansa jatkanut tai myöhemmin muuhun yritystoimintaan keskittynyt oli aloittanut muun yritystoiminnan harjoittamisen jo 1980-luvulla.

Päätöstä monialaisena jatkamisesta ei tehdä pelkästään taloudellisten syiden perusteella. Maatalouden harjoittamisen lopettaneissa on mukana myös isoja maatiloja. Voidaan olettaa, että heillä olisi ollut menestymisen mahdollisuuksia myös maatalouden harjoittamisessa. Toisaalta myös pienet maatilat ovat keskittyneet maatalouden harjoittamiseen. Mahdollisesti muu yritystoiminta ei ole kehittynyt toivotulla tavalla.

Tarkasteltaessa yritysjoukkoa kokonaisuutena voidaan todeta, että sekä maataloutta että muuta yritystoimintaa on kehitetty yhtäläisesti. Yritysjoukon yhteenlaskettu reaalinen liikevaihto oli pysynyt lähes muuttumattomana. Liikevaihdolla mitattuna yritysjoukon harjoittama maatalous ja muu yritystoiminta ovat olleet suunnilleen samansuuruisia ja niiden liikevaihto on kehittynyt samansuuntaisesti.

Vaikka osa monialaisista tiloista oli muuttanut yritystason strategiaansa vuosina 2001-2012, näyttää siltä, että monialaistamisstrategia on ollut toimiva tutkimustiloilla. Valtaosa on toiminut monialaisena kauan ja jatkaa edelleen monialaisena. Monialaisena jatkavilla maatiloilla oli isompi liikevaihto kuin muilla strategiaryhmillä ja heidän oman arvionsa mukaan, he ovat menestyneet yhtä hyvin kuin muut ryhmät. Tämä löydös tukee aikaisempia havaintoja (mm. Torkko 2006; Rantamäki-Lahtinen 2004) siitä, että monialaisuus ei ole pelkkä siirtymävaihe maataloudesta muuhun yritystoimintaan.

\section{Kirjallisuus}

Ansoff, I. 1987. Corporate strategy. revised ed. Bungay, UK: Richard Clay Ltd. 284 s.

Bamberger, I. \& Bonacker, R. 1994. Strategies of small and medium-sized enterprises and their measurement. In: I. Bamberger (ed.) Product/Market Strategies of Small and Mediumsized Enterprises. Avebury, Aldershot: 28-85. 
European Commission. 2008. Other gainful activities: pluriactivity and farm diversification in EU-27. Draft Note: Directorate G. Economic Analysperspectives and Evaluation LBT D(2008)17488. European Commission. Saatavana: http://ec.europa.eu/agriculture/analysis/markets/gainful/text_en.pdf: 1-43 p.

Hofer C.W. \& Schendel D. 1978. Strategy Formulation: Analytical Concepts. West Publishing Co, St. Paul, Minnesota.

Kay, R.D., Edwards, W.M. \& Duffy, P. 2008. Farm management. 6468th ed. New York, NY, USA: McGraw-Hill International Editions.

Lassila, H. 2005. Matkailutilan sukupolvenvaihdos talonpoikaisten arvojen ohjaamana prosessina. Jyväskylä studies in business and economics 40. Jyväskylän yliopisto, Jyväskylä.

McElwee, G. 2006. Farmers as Entrepreneurs: Developing Competitive Skills. Journal of Developmental Entrepreneurship 11, 3: 187-206.

MMMTike, 2011. Maatalouslaskenta 2010. Monialaiset maatalous- ja puutarhayritykset. Päivitetty 29.6.2011. Saatavana: http://www.maataloustilastot.fi/e-lehti-2011-06-29/index.html: 1-15.

Nickerson, N. P., Black, R. J. \& McCool, S. F. 2001. Agritourism: Motivations behind Farm/Ranch Business Diversification. Journal of Travel Research 2001, 40: 19-26.

Rantamäki-Lahtinen, L. 2002. Monta rautaa tulessa - monialaisten tilojen vertailu muihin maaseutuyrityksiin. Selvityksiä 14. Maa- ja elintarviketalouden tutkimuskeskus. Helsinki: 1-40 p.

Rantamäki-Lahtinen, L. 2004. Maatilojen monialaistaminen: empiirinen analyysi monialaisuuteen vaikuttavista tekijöistä. Maa- Ja Elintarviketalous 50, MTT Agrifood Research. Vammala.

Rantamäki-Lahtinen, L., Vesala, H., Vesala, K., Ylätalo, M., Karttunen, J. \& Tuure, V-M. 2007: How to measure success in rural small business? In International council for small business 52nd world conference 13th-15th June. Conference proceedins (CD rom). Turku School of Economics. $23 \mathrm{~s}$.

Rantamäki-Lahtinen, L. 2009. The success of the diversified farm - resource-based view. Agricultural and Food Science 18, Supplement 1: 1-134.

Rantamäki-Lahtinen, L. 2013. (toim.) Muuttuva ja menestyvä maaseutuyrittäjyys 2000-2013. MTT Raportti 116. Saatavana: http://www.mtt.fi/mttraportti/pdf/mttraportti116.pdf

Tike 2004. Maatilojen muu yritystoiminta. Maatalouden rakennetutkimus 2003. Tike. Helsinki: 1-28 p.

Tike 2011. Maatalouslaskenta 2010. Monialaiset maa- ja puutarhatalousyritykset. Maatalouslaskenta 2010

Torkko, M. 2006. Maatilakytkentäisten yritysten toimintamalleja: laadullinen tutkimus resursseista, kehittymisestä ja ohjaustarpeista. Oulu: Oulun yliopisto. Acta Universitatis Ouluensis 239.

Vik, J. \& McElwee, G. 2011. Diversification and the Entrepreneurial Motivations of Farmers in Norway. Journal of Small Business Management 49, 3: 390-410. 